\title{
Post-2015 Refugees Welcome Initiatives in Sweden: Cosmopolitan Underpinnings
}

\author{
Maja Povrzanović Frykman and Fanny Mäkelä
}

\section{Introduction: Moral and Political Dimensions of COSMOPOLITANISM}

Researchers have shown that seemingly "apolitical" volunteering for refugees framed within humanitarian parameters is actually highly political. Fleischmann and Steinhilper's (2017) review of research on the upsurge in German citizens' commitment to refugees in 2015 suggests that, by avoiding politically contextualising their own work, volunteers became complicit in an increasingly repressive migration regime that reproduces hegemonic inequalities and hierarchies. On the other hand, these authors point out the potential of current volunteering for initiating political transformations, in line with Rancière's $(1999,2010)$ understanding of the political as a "rupture" in the dominant order. They see unique points of access for refugees

\footnotetext{
M. Povrzanović Frykman ( $₫)$

Faculty of Culture and Society, Department of Global Political Studies, Malmö

University, Malmö, Sweden

e-mail: maja.frykman@mau.se

F. Mäkelä

Malmö, Sweden

(C) The Author(s) 2020

O. Hemer et al. (eds.), Conviviality at the Crossroads, https://doi.org/10.1007/978-3-030-28979-9_9
} 
to German society, but also political possibilities that foster change towards more egalitarian relations, in spaces of encounters similar to those described in this volume by Duru (Chapter 7) and Cory (Chapter 8 ). While these and several other chapters in this volume make a strong case for conviviality as a notion that is opening new analytical venues, the following chapter takes a step back and deals with the cosmopolitan values and visions in which potential modes of conviviality may be grounded. Relating to a specific historical conjuncture of refugee migration and altered mobility regimes, this chapter focuses on Refugees Welcome initiatives in Sweden, notably in the post-2015 context. We thus respond to Braidotti et al. (2013: 3) call for an understanding of cosmopolitanism that is "more attentive to the material reality of our social and political situation ... with specificity rather than generality, groundedness rather than abstractness". In line with Skrbiš and Woodward's (2013: ix) statement in the preface to their book on the uses of the idea of cosmopolitanism, we do not see it as "a hallelujah moment for social scientists trying to conceptualise a better society", but as a process which allows for moving closer to the possible cosmopolitan ideal-a process that requires engaging by doing.

Recognising the shortcomings of applying cosmopolitanism as a normative concept to empirical realities of "living-with-difference" (see Nowicka, Chapter 2 in this volume), we do not discuss the newly created spaces of encounters between refugees and residents but analyse Refugees Welcome initiatives' cosmopolitan underpinnings. We employ it as a concept that may help us understand how particular and universal concerns and aspirations for social justice are conjoined in a specific setting of volunteering and activism in Sweden after 2015.

Reviewing the literature dealing with the moral, political (or legal) and cultural cosmopolitan doctrine, and how each represents the impact of the idea of universal membership (or world citizenship) on morality, political institutions and cultural identity (Etinson 2011), is beyond the scope of this chapter. For the attempted analysis, we find useful the differentiation between the moral and the political/institutional dimension of cosmopolitanism (Held 2013). ${ }^{\mathrm{l}}$ It helps us discern the view of all human beings requiring equal moral respect and concern from an institutional focus that is occupied with questions about how cosmopolitan principles can be embedded in practice.

As stated by Held (2013), the principles of equal respect, equal concern and the priority of the vital needs of all human beings are not principles for some remote utopia (see Lettevall, Chapter 5 in this volume); existent forms of political regulation and law-making create powers, rights and constraints 
that go beyond the claims of nation states. However, as will be displayed below, the realities of unequal political treatment of those whose chances and choices are distorted by the luck (Brock 2019) of having been born in/belonging to a war-ridden country are a source of great frustration for pro-refugee volunteers and activists. While trying to act upon their values that we frame as cosmopolitan, they face the limitations imposed by Swedish legal and political context that are part of how "current global systems are failing the ethical concerns of moral cosmopolitanism" (Held 2013: 30).

In the following sections, we briefly provide background information about the emergence of Refugees Welcome initiatives in 2015, review relevant former research and present our interview material. We then analyse our interviewees' reflections on their volunteering and activism through the lens of cosmopolitanism. In the concluding section, we relate our results to the theoretical work on cosmopolitanism that specifically sets it in the context of recent refugee migration (Caraus and Parvu 2019).

\section{BACKGROUND}

The official refugee reception services in Sweden, and in the city of Malmö in particular, faced an unprecedented challenge when more than two-thirds of the 163,000 asylum seekers entering Sweden in 2015 arrived in the last four months of the year. ${ }^{2}$ It took six weeks for the authorities to respond and in their absence civil society (Spurk 2010) stepped in. Volunteers under the banners of different formal and informal civil society organisations, Christian, Islamic and Jewish congregations and individuals, managed the overwhelming situation in Malmö where up to 2000 refugees were being received on a daily basis. They welcomed them and provided donated clothes and refreshments, sanitary products and toys, information and practical guidance, money for their continued journey or shelter for the night (Povrzanović Frykman and Mäkelä 2019).

The volunteers managed the situation widely perceived as "crisis" that was overwhelming in both practical and emotional terms. Kontrapunkt-a cultural and social centre promoting activism, volunteering and personal engagement that proclaimed support for refugees long before the events of 2015 (Povrzanović Frykman 2016)-became one of the most prominent places where refugees were assisted by over 1100 volunteers. Between September and November, 1000 portions of food were cooked and served there daily (Rescala 2016). 
This reinforced the existing image of $\mathrm{Malmö}^{3}$ as "the capital of solidarity" characterised by the presence of a strong and prominently leftist civil society (Hansen 2019), ${ }^{4}$ but also brought to the fore internal differentiation already present prior to the 2015 "crisis", between formal and informal organisations and between "ordinary" volunteers and "activists", where "activism" denotes leftist political engagement. Moreover, it actualised the dilemma of whether civil society groups should compete with or attempt to substitute state activities (Pries 2019), while the unprecedented civil society engagement actually replaced the authorities that were unprepared for taking full control of their mandate.

As the level of emotions and devotion to the task was high, the people participating in the civil society response were utterly frustrated when they were eventually replaced by officials and professionals, dismissed as "only volunteers" and forbidden to offer any donated food to the incoming refugees. The disbelief and shock-described by many as a truly traumatic moment - came on 21 November 2015 when the Swedish government introduced checkpoints at the Swedish border with Denmark, at which the incoming people could be prevented from entering the country (Povrzanović Frykman and Mäkelä 2019).

While Kontrapunkt recognised the urgency of volunteering but retained high profile in left-wing extra-parliamentary political activism, Refugees Welcome to Malmö made it clear that they were politically and religiously unattached, making it easier for them to cooperate with state officials. They had 800 volunteers and most of our interviewees (see ibid.) stated that they joined Refugees Welcome to Malmö because it did not take sides: there was no conflict between their humanitarian ambition and personal political and religious beliefs. In 2015, the impetus for immediate humanitarian effort stemmed from the image of "crisis" (Fassin 2016), and it ceased once the refugees stopped entering Sweden in large numbers. During the autumn of 2015 a lot of Refugees Welcome initiatives popped up in cities all over Sweden, but only a few of the spontaneous volunteers' initiatives evolved into NGOs. However, a number of new civil initiatives and organisations have emerged in the aftermath of the events of 2015. Refugees Welcome Sweden died out, but was resurrected and is today an umbrella association that focuses on providing a structure and aid to local initiatives with the refugees, as well as working to strengthen support in Sweden for what they call "a long-lasting and humane asylum system in Sweden". 5 


\section{FORMER RESEARCH}

Civil society in Sweden has been studied previously (Svedberg and Trägårdh 2006), but little attention has been paid to the grass-roots initiatives of 2015 discussed in this chapter. Initial research was done mostly by students who addressed the questions of motivation (Mäkelä 2016; Rescala 2016), internal competition (Ghita 2016), compassion and perceptions of volunteers' own privilege (Mårs 2016). Our research explored the volunteers' motivations, but also conflicts and political ambiguities within the Refugees Welcome to Malmö civil initiative (Povrzanović Frykman and Mäkelä 2019). A study comparing the situation in Sweden and Germany focuses on emotional aspects of pro-refugee mobilisations (see Kleres 2018), while a recent volume presenting the state of the art of research on Refugees Welcome initiatives in Europe (Feischmidt et al. 2019) provides insights into manifold tensions between motives, idea(l)s and outcomes in the field of volunteering (see e.g. Karakayali 2019; Turinsky and Nowicka 2019; Vandevoordt and Verschraegen 2019) that are highly pertinent to the discussion this volume invites on perceptions of difference, practices of inclusion and feelings of obligation, and the ways of theorising them. This chapter contributes to the literature that seeks to understand the social and political developments of Refugees Welcome initiatives beyond the immediacy of "crisis" (e.g. Fleischmann and Steinhilper 2017; Funk 2016; Jäckle and König 2017). In addition, contributions are made to the understanding of motivations and experiences of volunteering and the "new" forms of volunteering that are autonomous and unaffiliated.

\section{The Material}

Our ongoing research is based on in-depth interviews conducted by Fanny Mäkelä in Malmö in 2016 and 2018 with the volunteers engaged in different Refugees Welcome initiatives in Sweden. ${ }^{6}$ The interviews conducted in 2016 focused on the experiences of people who were practically involved in Refugees Welcome to Malmö in the autumn of 2015, while the interviews from 2018 focused on post- 2015 context and the volunteers' reflections on the dynamics of value-based visions guiding their work and the practical outcomes of that work. ${ }^{7}$

The body of material includes 18 interviews with men and women ranging from 22 to 68 years of age (at the time of interviewing), in various professions, and with different levels of education. Political party sympathies 
cover a wide spectrum; however, most of the interviewees voted for the Left Party (Vänsterpartiet). About half of the interviewees have a Swedish origin, while others come from a number of different countries and continents. ${ }^{8}$

In this chapter, we focus on the perceptions and self-reflections of four persons who have had a prominent role in the post-2015 Refugees Welcome initiatives in Sweden.

Tobias is 47 , has a university education and works as a coordinator for families hosting young homeless people. He is of Danish background but has lived in Sweden for 30 years. Prior to 2015, Tobias engaged in voluntary work with asylum seeking Palestinians and human rights work with the Roma people in Malmö, who are mostly from Romania. Besides being engaged in Refugees Welcome Sweden in 2015, he is the initiator and chairman of a post-2015 national umbrella version of this organisation.

Gemila is 33, holds a university degree and works as head of the unit for accommodations for unaccompanied minors. Gemila's mother is Polish, her father is Iraqi and she has lived in Sweden for 29 years. Before 2015, she volunteered in a Red Cross women's shelter. Besides being engaged in the board of Refugees Welcome Sweden, she is the initiator and chairperson of post-2015 Refugees Welcome Malmö.

Kamal is 30 years old and came to Sweden from Lebanon with his family in the 1990s. He is a teacher, but for the moment he works with coordinating the official refugee reception and inclusion in the municipality where he lives. On the 7 September 2015, he started Konvoj för medmänsklighet (Convoy for humanity) with cars driving through Europe and back to Sweden picking up refugees, creating a safe way to seek asylum. He simultaneously founded a local Refugees Welcome initiative which today has a regional scope with himself as chairman; he is also a member of the board in Refugees Welcome Sweden. Before the autumn of 2015, Kamal had some experience of volunteering with the collection and distribution of clothes to homeless in the local foundation Glöm aldrig William Petzäll.

Kajsa, our fourth interviewee quoted, is a Swedish born 27-year-old, holds a university degree and works professionally as a project leader. Prior to 2015, she was volunteering in The Swedish Network of Refugee Support (FARR), ${ }^{9}$ No One is Illegal ${ }^{10}$ and the Asylum Group. ${ }^{11}$ Kajsa was involved in the refugee reception from the start and is the national coordinator of Refugees Welcome Housing ${ }^{12}$ - one of the organisations that are part of the Refugees Welcome Sweden network. They recognise a need for alternative accommodations and hence match landlords with asylum seeking refugees, 
refugees with a temporary residence permit, and refugees that have been denied asylum and therefore live in Sweden "illegally". They do this in order to fight isolation and create a culture of mutual integration.

\section{Specificities of the Swedish ConteXt-And Its Changes}

In the Swedish cultural context, the Social Democratic idea of folkhemmet- "the people's home"-is crucial for understanding the background of our interviewees' views and values. Every citizen is protected "from the cradle to the grave" by a number of social rights (Lewin 2013: 30). In 1928, Per Albin Hansson used the family as a metaphor and stated that in a family no one looks down on the other, no one tries to get an advantage on another's expense and the strong don't prey on the weak. In the good home, there is equality, care, cooperation and helpfulness (ibid.). Folkhemmet has thus created fundamental values of equality and social justice that permeated Swedish society for over 90 years-the values that our interviewees repeatedly referred to. Sweden, widely viewed both domestically and internationally to be "a champion of high global morals" (Tanner 2016), has been historically refugee-friendly, receiving resettled refugees through the United Nations since 1950. Moreover, Tobias sees the civil engagement for asylum seekers as embedded in a particular tradition of civic movements in the country:

We had a luxury situation here in Sweden, that people could organise - and we should use this! I like the notion of folkrörelse - civic movement. We have a unique history of folkrörelse here in Sweden. The workers' movement, women's movement, peace movement, environmental movement. We have a history as a people rich in movements.

As the quote suggests, Tobias is optimistic about the potential of the Refugees Welcome movement in Sweden. However, the other interviewees quoted here do not share his optimism. Kajsa observed that many of the people who volunteered at Malmö Central station in 2015 now, years later, do not consider that those who arrived are still in Sweden waiting for residence permits. ${ }^{13}$ Gemila also talked about issues of disinterest and a lack of commitment. In 2017, she tried to start up a local Refugees Welcome initiative in the county where she worked at that time. She called meetings and "people came, but there was no one who wanted to get involved, the 
engagement had died out". In the winter of 2017 back in Malmö, she tried reviving the old Refugees Welcome to Malmö, "but it also died pretty quickly actually, the name bore it, but it died".

Kamal's story starts with the opportunity to practice solidarity, but leads to failing engagement as a result of the political context:

In Autumn $2015, \ldots$ it was all we learnt about Sweden that we grew up in ... about what my [with emphasis] Sweden is. [pause] It was now we could practice it. It was now that we could show what we were raised like and we had the country with us. So, we started to do things, together we built these groups, and people just said "yes, of course", ... "sure, what can I do", no question about it, "we do it". [pause] "we do it". [pause] And I thought, this is what activism is about, we can change the world! But it is not like that. The moment Sweden changed its official standpoint, it took the air out of the entire movement. Then instead it was "yes, we do what we can even if our state does not succeed with it - so we do what we can", but then it was "we do what we can but the state is also against us". So it was like it, it pulled the air out of everything [with emphasis] and it was like all of those [volunteers] who have spent a lot of time but were really not familiar with this, they disappeared, it was the outermost circle that usually never participates, they disappeared. The core remained, and the core got smaller and smaller with fewer people who were the most active, and many burnt themselves out and many quit.

From having had one of the most generous refugee and asylum policies in Europe, the Swedish government began adopting stricter legislation and policy reforms to narrow benefits for refugees (Tanner 2016) and, as presented at the Asylum Group's webpage, ${ }^{14}$ implementing "a systematic rejective refugee politics". Kamal stated: "We are betraying all our ideals, we... we are abandoning everything we have learnt is right". Kajsa gets very frustrated by the politicians' picture of refugee reception and the way this picture is accepted by the general public without any questions being asked. Since late 2015 with the closing of the borders all she hears is,

the discussion that 'we cannot manage any more' - that one can believe that Sweden as a privileged country can exist in a global world without taking part in the consequences of the wars and catastrophes that take place in the world! 
Kamal puts a lot of blame on the government consisting of the Social Democrats and the Green party for the change in values among the population. By endorsing the right-wing position concerning refugees as a burden, they made volunteers "feel ashamed for being humane", as if it was "wrong to work for a better world". Tobias instead sees the changes in treatment of refugees by the Swedish state in a broader context of "the Western world" closing its ranks to protect its privileges:

This what happens in the Western world - that we would not be able to help people, that is exaggerated, that is sick, to be a part of the problem and not take responsibility! It is defect.

This strong stance points to the "defect"-even "sick", morally unattainable-character of this non-recognition of shared responsibilities. Similarly to Gemila's remark that "we have lost the core values of what it means to be human", it resonates with the cosmopolitan ideal of the global civil society discussed by Hensby and O'Byrne (2019), who see it as both a normative project and a space for ethical debate. Indeed, the fundamentally ethical dimension of civic engagement for refugees-in direct relation to Held's (2013) moral cosmopolitanism-comes forward in our interviewees' reflections on the values guiding their volunteering and advocacy work, discussed in the following section.

\section{Cosmopolitan Values, Moral Obligation}

"The reason I engage is not because engaging gives me, like, a warm and cosy feeling”, said Gemila. Similarly, Kajsa stated: “One doesn't engage because it is fun. One can just continue living one's own life. It is about solidarity, it feels important". When describing the situation with refugee arrivals to Malmö Central station in 2015, Tobias presented it as a moment of "enormous solidarity", where asylum seekers "were welcomed by fellow humans". He further explained that he lived for longer periods "in other cultures", learned other languages, and therefore, "cares very much for globalisation issues that are incredibly important today":

I think that borders have a lesser importance in a globalised society we live in today. That is why migration issues are so incredibly important. Because people, for different reasons, must move in this world. And we have one world and I think that one has to be able to move freely in the entire world. 
Since we ourselves cause many of the reasons that force people to move. All from environmental catastrophes to war, persecution and so on. So, to lock people out from settling and living in freedom is fully incomprehensible. These are, approximately, the basic values I have in my work.

This quote clearly positions Tobias as a person who does not see the refugees just as "needy others", but who understands global connections and disparities of privilege in the "one world we have" and thus claims shared responsibilities. He also said that "if one stretches it really far politically, it is often the Westerners themselves who caused many of those problems in parts of the world that are in crisis".

Without presenting himself as cosmopolitan, Tobias adheres to the cosmopolitan principle that "highlights the responsibilities we have to those whom we do not know, but whose lives should be of concern to us" (Brock 2019: 315). Furthermore, he appears as cosmopolitan as he communicates "a reflexive and critical engagement with globalization" (Hensby and O’Byrne 2019: 336):

I want us to work for a globalized world, where we can use each other positively, help each other, and share. We otherwise counteract our own existence, for, like, no man is an island, as they say [he laughs], so it is. So, this what we detect now, I feel it is a favour of a kind, to participate in what is happening. It feels a bit like, it is now that the vital decisions are made and how we want to have it: is it a more closed world or do we go towards a more open world - that is where we stand and try to weigh now. (...) Refugees Welcome-movement can hopefully be a seed of a more open world.

\section{Recognising Difference, Recognising Agency}

Cosmopolitanism engages ideas around identity and difference (Moore 2013) and the critique of cosmopolitanism points out that it reinforces fixed categories of human difference originating from the colonial past. As Nowicka (forthcoming) argues, "reduced to moral obligation to humanity, cosmopolitanism inadequately addresses the challenges of relationship with the other, for even if we are all humans, we are all different, and this difference matters" (see also Nowicka, Chapter 2 in this volume). Importantly, in our material the recognition of difference does not imply othering, but is rather in line with the rejection of a stance that-as succinctly phrased by Erikson (Chapter 3 in this volume)-difference is a threat and sameness is a 
prerequisite for sharing. Or, as in Gemila's elliptic formulation concerning the refugees: “They are no fucking Aliens! They aren't; they are people as any other people".

When saying "I have heard such histories, it cannot be described, I don't know what it is that makes people want to continue living!", Tobias appears shaken by the encounters that made him acutely aware of his own privileges. At the same time, he is aware of the oppressive character of the categories, based on legal status or recognition of neediness, that reduce refugees to victims and deny their agency:

These people have been through so much, there is nothing to say. And then, to come to a society that is oppressing you or taking away your rights, to live as a part of some kind of statistics, that is for me totally beyond understanding it is people, and each and every one has a personal story that is their reason for coming here. One should listen to them, not lump them together as 'refugees' or one or another 'group'. No, one should not do that. I understand the need, but no. That is what is motivating me in this work, to actually lift people who are incredibly vulnerable, who absolutely don't have any reason to 'be victims'. They are victims, but they did not put themselves in such position.

This resonates with Fine's (2019) warning placed in the context of discussion of cosmopolitan solidarity: "If we turn victimhood into a master status, we are faced with the paradox that compassion for the victims can also strip them of their humanity" (Fine 2019: 368).

Tobias means that refugees should not only feel welcome, but that they should also treat their experience as refugees as part of their life, rather than as a discrete event, and build on that experience as they continue living in Sweden. He further maintains that it is important to work with the asylum seekers and not for them. However, including the asylum seekers in Refugees Welcome initiatives is a major problem. Even if there are instances of (former undocumented) asylum seekers becoming prominent activists (see Hansen 2019), the volunteers cannot work in an inclusive way to the extent that they wish. Tobias explained that "the asylum seekers are afraid of engaging, they believe it is not good for their 'case", i.e. the possibility of getting residence permit. When they eventually receive a residence permit, possibly after seven years, their life starts, but the "bubble" of waiting in uncertainty has torn a person "to no worth at all". An entire life starts again, and their first priority is not to get engaged in volunteering or in political activism. However, ideally, Tobias claims, the pro-humane asylum 
politics movement should be led by people with personal experience of asylum seeking.

Tobias also worked with stateless Palestinians who "had a very difficult asylum process in Sweden". He recounted problems where Palestinians who had lived in Sweden for seven or eight years without receiving residence permits behaved negatively towards the Syrians who obtained permits far more quickly. Finding himself "involved in a Middle Eastern thing" as a mediator between two camps "felt fully bizarre", but enabled learning and understanding:

Sitting between two groups of very frustrated men and trying to reach some kind of Swedish consensus - that was just impossible! But one learned incredibly much. I have such a great respect for different cultures, how one mediates, and how one acts - it is a very big lesson learned that I wish I had gotten more of. ... It was an interesting and important experience that helps in working with refugees.

I have worked so much with the anti-Semitic part that there is - it is so deeply rooted and, in a way, it is very difficult to deal with. You must have an understanding for it in order to try to process it. One will never be able to understand fully, but it is very important to have an insight, to understand the frustration, and anger. We have had a luxury of living here!

What Tobias recounted was a lesson in how cosmopolitanism needs to be situated in the social situations here and now as well as in the concreteness of historical contingencies elsewhere in the world (Pendenza 2017). As noted by Trujillo (2015), cosmopolitanism that seeks to overcome existing differences presupposes their existence and the possible tension between them. The political dimension of cosmopolitanism thus regards "a dynamic effort for increasing inclusion in a single community, whilst maintaining differences" (Trujillo 2015: 13). ${ }^{15}$

\section{RELATION TO INSTITUTIONS: INTEGRATIVE VS. TRANSFORMATIVE Role?}

The interviewees quoted in this chapter hold prominent positions in the post-2015 pro-refugee and pro-humane asylum politics movement in Sweden and have a strong voice in formulating its principles and goals. The way they frame their engagement confirms Hensby and O'Byrne's (2019: 339) 
observation about a fundamentally ethical dimension of civil society. However, the felt necessity of doing something about the perceived injustices here and now-in this case concerning asylum seekers in Sweden-brings to the fore the tension between integrative and transformative aspects of civil engagement that these authors see as an undercurrent of civil society today in general. By working with (or even instead of) existent institutions of state and municipalities, the volunteers risk the trap of working with "passion for compassion devoid of politics" (Wilkinson 2019: 379), ignoring the institutional side of the refugees' problems. This is obvious and frustrating to our highly politically conscious interviewees. Gemila, for example, made a cynical comment:

What volunteers do is that they are scraping what society like, stepped on [...] volunteers 'feed the cats in the backyard', [pause] those summer cats that no one wanted, so. Like that which society failed to take care of, the things they dropped, there the volunteers and the civil society step in.

Kajsa holds that civil society "takes much more responsibility than it should" and that "the state should take more responsibility instead". However, she sees civil society as an important "catalyst" for positive change. This change refers to, for example, how people who live with refugees due to the Refugees Welcome Housing initiative, "can understand how twisted the entire Swedish asylum system really works". Kajsa sees this as very important, since Swedish citizens who are voting with regard to migration issues should know the legal and institutional realities of those issues.

While engaging in work to shift public and state opinion in Sweden towards support for a society where everyone's equal worth is mirrored in politics, these volunteers also engage in direct contact with asylum seekers to facilitate the fulfilment of those asylum seekers' urgent needs. They express a kind of pragmatic realism about their own potential influence, as seen in Kamal's reflections on the start of his volunteering in 2015: "I started at the wrong end, I wanted to have big changes, I should have started with the small ones". Gemila says that it has been good for her to professionally work for a municipality, since "one learns a lot".

At the Refugees Welcome Sweden webpage, a collaborative approach is promoted: "We believe that cooperation between governments, agencies, non-profits, and citizens is critical to create a long-lasting and humane asylum system in Sweden" (http://www.rwsverige.se/about/). Tobias said he considered collaboration with the municipalities and the Swedish 
Church as the best way of addressing specific local needs concerning refugees, since "no one has all solutions and answers". Similarly, Kajsa stated:

Migration is a challenge for the entire society. The authorities cannot resolve it on their own; private persons should not resolve in on their own. There is a need for organising and strategic thinking engaging several different actors, to find good solutions for the individuals.

Gemila dismisses the current Swedish asylum regime as "offensive" and "inhumane":

I never believed that Sweden would end up where we are today, no one is doing anything, everyone just stands there and looks and thinks "this is a necessary evil". We are letting people drown in the Mediterranean Sea because it is a 'necessary evil'; [pretends to be upset] "God forbid that I should pay 20 kronor more in taxation, oh my God! Think if I cannot buy a new iPhone as Christmas present for my children since a damned refugee should come here!".

For Gemila, the current politics is the greatest obstacle, together with the society in which civic engagement is fading away- "on the way to die out", and at the same time the activists are "hitting the wall, all of them". When asked about her motivation for volunteering and activism after 2015, Gemila said she feels that what she does working with refugees professionally is not enough. Moreover, she presented an instance of historical reflexivity (see Glick Schiller 2016) in proposing a very dark possible future:

I feel that [long pause] I want to have done something, I don't want to have stood there and not have, or at least not have tried to influence. [long pause] Because when I sit in a camp, with [long laughter] with a number on my arm, I don't want to say "I didn't know, I didn't see it coming", to be completely honest.

Both Tobias and Kamal wish that Refugees Welcome should not (need to) exist. Kamal dreams of "a world without refugees based on problems with human cause, social problems, problems with war": 
I believe in, [pause] I am such a naive person who still believes in world peace. I think the only way to stop the refugee, if I may dream - that is what we should work with, to stop the war, to be a peace movement, a new peace movement.

While Kamal goes to the core of the problem by emphasising that stopping the war is "the only honorable way" of dealing with refugees, Tobias focused on Sweden where he sees civil society as the only humane alternative to the authorities and their paragrafrytteri, a Swedish expression for a kind of cynical and numerical legalism and machinelike administration. $\mathrm{He}$ hopes to be able to contribute to political change in Sweden and to create "a more compassionate system, humane in the process, a more humane system":

Compassion should be the guiding star of political decisions, but I think that we [Refugees Welcome movement in Sweden] first and foremost must act politically; we must, as the questions of migration are political. So, if we should influence, we must do it politically, influence for compassion, turn compassion into politics.... I want to be a good person, not a good politician.

These words, again, resonate with theoretical discussion of cosmopolitanism, namely with Fine's (2019) understanding of cosmopolitan solidarity that is fundamentally built upon compassion. However, unlike compassion's nature as a matter of emotion and subjective consideration, solidarity is "a legal and political concept, denoting a shared responsibility for seeing through a particular project" (ibid., 368).

While Gemila hinted at the moral controversies of humanitarian practice (Wilkinson 2019) when stating that the Refugees Welcome movement will always be a humanitarian movement since they are working with a humanitarian vulnerable group, Kamal outlined the dilemma more clearly. A rhetorical question he posed about Refugees Welcome's actual purpose made clear the dilemma between the integrative, system-supportive and the transformative, system-changing roles of civil society:

To work with the refugees and their rights, yes, it sounds good, but what does it mean in practice - is it about language cafés? There are other groups [to engage with that] I believe, I think we should engage in opinion building. 


\section{Conclusion}

This chapter exemplified how the moral and political dimensions of cosmopolitanism (Held 2013) are intertwined in pro-refugee volunteering and activism. Our analysis displayed how cosmopolitanism can point to the universal aim of equality and at the same time demand that it is realised locally (Trujillo 2015). None of our interviewees employed the notion of cosmopolitanism when reflecting on their engagement with and for refugees. However, they outlined a normative order that emerges as a political project towards a reconstruction of society along lines of equality and justice (Siapera 2019), in line with the statement found at their organisation's webpage: "Refugees Welcome Sweden envisions a world where people are free from war, persecution and institutional discrimination. It is our mission to make Sweden a welcoming place for all refugees" (http:// www.rwsverige.se/). The analysed narratives communicate the position of moral cosmopolitanism that, as pointed out by Held (2013: 30) translates into duties of global justice, to the protection of universal human rights, and to reforming unjust systems so that they are in line with cosmopolitan moral principles. It does not appear as a desired but chimeric "fantasy" (see Nowicka, Chapter 2 in this volume), but rather as "a concrete objective, a foreseeable situation, capable of being achieved in our world. ... a goal that needs to be formulated, cultivated and promoted" (Cebolla and Ghia 2015: 4). Indeed, our interviewees do not only talk about principles but put them into action: they initiated and lead a solidarity organisation with a number of sub-organisations specialised in practical work with refugees as well as in opinion building; they work to incite others to engage; and they are involved in day-to-day activities with refugees. We delved into the individual level of processes that require engaging by doing (Skrbiš and Woodward 2013), and we hope this chapter makes a convincing case for the analytical benefits of such an approach. At the same time, we analysed aspirations as situated in the social dynamics of volunteers' groups and organisations and as anchored in the historical context of specific societal values (Pendenza 2017).

The interview excerpts we presented do not reproduce universalising narratives, but resonate with a critical cosmopolitan stance (see Delanty 2006) described by Glick Schiller and Irving (2015: 5) as "aspirational, self-problematizing and aware of incomplete and contested nature of any cosmopolitan claim". Opposite to seemingly "apolitical" volunteering for 
refugees framed within humanitarian parameters, our interviewees' engagement clearly attempts political change. They understand that the institutionalisation of what we see as cosmopolitan principles guiding their work requires the entrenchment of these principles in law and public fora at diverse levels (Held 2013). Their ultimate aim is that their volunteering should become superfluous - when a "lasting and humane" asylum system is established in Sweden and the responsible institutions truly take over the task of helping asylum seekers, while granting them room for defining their needs and exercising their agency.

Scholars have observed that "the extent to which civil society movements have been able to induce political reforms to prevent the reproduction of social inequalities has historically been one of its key shortcomings" (Hensby and O'Byrne 2019: 339). A thorough understanding of the role of post-2015 Refugees Welcome initiatives in political transformations in Sweden remains a matter of further research. However, this chapter made clear the need to situate the analysis in a broader political context. In the case of post-2015 Refugees Welcome initiatives, this proved to be overwhelmingly important for understanding why the unprecedented civil society engagement for refugees met its abrupt end, but also why the principles it is based on present a sound ground upon which it may be resurrected as a political project.

In conclusion, we would like to relate our results to Caraus and Parvu's (2019) inspiring attempt to theorise cosmopolitanism by setting it in the context of refugee migration (see also Caraus and Paris 2019). They see migration and cosmopolitanism as consubstantial, since migration, without impediments, is a given starting point for a cosmopolitan "citizen of the world". Focusing on undocumented migrants' protests that are opposing anti-cosmopolitan stances generated by the increasing numbers of refugees and economic migrants, these authors develop a novel notion of radical cosmopolitanism. It refers to a bottom-up politicisation through antideportation protests of undocumented persons, organised by the movements such as Sans Papiers, No Borders and No One Is Illegal, that "contain in nuce new demands and new visions of the world" (Caraus and Parvu 2019: 426). Caraus and Parvu (ibid., 420) see these protests as acts of cosmopolitan citizenship that contest existent terms of political community and identity; they point at the "radical cosmopolitan potential" of such acts. They claim that such "migrant activism is inherently cosmopolitan" and "has a direct cosmopolitanizing effect" (ibid., 425), as the very act of protesting contests border regimes of nation states and thereby projects 
the world without borders or with porous borders. These authors point to "the quiet, invisible transformation of the world" that takes place when migrants "clandestinely defy the borders and expose the contingencies of citizenship without ever intending it" (ibid.).

In consent with this view, we propose to enlarge its scope to the activists and volunteers such as the ones involved in post-2015 Refugees Welcome initiatives in Sweden. Their intended political goals grounded in the claim of rights for human beings and not for citizens of a particular state, their rejection of the category of "illegal" people and any categorical units of difference, their work with refugees, including the demonstrations they co-organise with undocumented migrants (see Hansen 2019), the lectures they organise, the texts they publish on their organisations' digital platforms, as well as their proneness to historical reflexivity and critical selfreflection, all contribute to a bottom-up cosmopolitanisation of presentday Sweden, hopefully with transformative effects that will allow for future modalities of convivial life to develop.

Acknowledgements We wish to express our profound thanks to the interviewees for their willingness to participate in our research.

\section{Notes}

1. "Moral cosmopolitanism often translates into corresponding duties of global justice, to the protection of universal human rights, and to reforming unjust international systems so that they are in line with cosmopolitan moral principles. This moral dimension can be related to, but can also be distinct from, institutional cosmopolitanism, which focuses primarily on examining what institutional designs might best implement the normative considerations of its moral counterpart" (Held 2013: 30).

2. In 2015 , Sweden had the highest number of asylum seekers per capita in the European Union, second only to Germany in absolute numbers, although first in terms of the number of people arriving from Syria. For more details, see Tanner (2016).

3. With a population of more than 330,000 , Malmö is Sweden's third largest city. The inhabitants' average age is 38.5 years and $48 \%$ of those between 25 and 64 years of age have tertiary education. They originate from 178 countries $(32 \%$ were born abroad and $12 \%$ have parents who were born in other countries) (Malmö stad 2016).

4. Focusing on the effects of the acts of prefigurative politics, Hansen's (2019) only touches upon Refugees Welcome in 2015. However, her ethnographic research on left-wing extra-parliamentary activism in Malmö is an important backdrop for the analysis attempted in this chapter. 
5. "Refugees Welcome Sverige is a Swedish non-profit organization that works to include refugees in the Swedish society. We believe that cooperation between governments, agencies, non-profits, and citizens is critical to create a longlasting and humane asylum system in Sweden. We believe that this is crucial in order for Sweden to continue being an open and compassionate country that promote and protect people's civil rights", http://www.rwsverige.se/, accessed July 1, 2019.

6. The interviews were conducted and transcribed by Mäkelä in Swedish. The quotes in the text are translated into English by both authors.

7. The notion of volunteer is used in this chapter as an umbrella term for anyone who engaged in volunteer work. However, while some people interviewed by Mäkelä stressed that they see themselves as volunteers but not as activists, the interviewees quoted in this chapter used both terms when reflecting on their own engagement and on Refugees Welcome initiatives in general. For discussion of ambiguity of the notion of activist in the context of left-wing activism in Malmö, see Hansen (2019).

8. For details on all research participants, see Povrzanović Frykman and Mäkelä (2019). A highly pertinent discussion of the implications of migrant origin in activism (see Glick Schiller 2015; Hansen 2019) is beyond the scope of this chapter. Let it suffice to note here that, when critically assessing current Swedish asylum politics, they used "we" to refer to "Sweden" and "the Swedes".

9. FARR (Flyktinggrupperna och Asylkommitteérnas Riksråd) is an umbrella organisation that supports on national scale individuals and groups that promote the right to seek asylum. For more details, see https://www.farr.se/ sv/in-english.

10. For details, see https://www.ingenillegal.org/english/.

11. The Asylum Group in Malmö is a non-profit organisation that works with and for asylum seekers and refugees on hiding since 1991. For more details, see http://asylgruppenimalmo.se/english/.

12. For details, see https://refugees-welcome.se/?lang=en. See also Welcome Housing Facebook page https://www.facebook.com/ refugeeswelcomesverige/posts/667049040169305/, where the following text is available in English and Swedish: "Let's share everyday life, society and the world. ... Refugees Welcome is Global-Global Solidarity".

13. In 2013, Swedish migration authorities decreed that all Syrians granted any form of protection would receive permanent residence, but two years later "Sweden rolled back its permanent residence policy for all newly arriving Syrians, and has proposed granting only temporary status to successful asylum seekers of all nationalities, including Syrians" (Tanner 2016).

14. "International conventions that Sweden has ratified are not being adhered to and gross violations of right to asylum occur. ... UN has given Sweden most 
attention for having sent people to countries where they are susceptible to torture," http://asylgruppenimalmo.se/english/, accessed June 1, 2019.

15. "In the inclusive versions of cosmopolitanism, a positive cosmopolitan claim is prevalent: the point is not to deny the relevance of necessary differences, but to build a balance between differences in a community of destiny. Cosmopolitanism is an aim to be achieved, presumably with continuous new challenges" (Trujillo 2015: 14).

\section{REFERENCES}

Braidotti, R., B. Blaagaard, and P. Hanafin. 2013. "Introduction." In After Cosmopolitanism, edited by R. Braidotti, P. Hanafin, and B. Blaagaard, 1-7. Abingdon: Routledge.

Brock, G. 2019. "Seeking Global Justice: What Kind of Equality Should Guide Cosmopolitans?" In Routledge International Handbook of Cosmopolitanism Studies, 2nd ed., edited by G. Delanty, 315-325. Abingdon: Routledge/Taylor \& Francis.

Caraus, T., and E. Paris, eds. 2019. Migration, Protest Movements and the Politics of Resistance: A Radical Political Philosophy of Cosmopolitanism. New York: Routledge.

Caraus, T., and C-A. Parvu. 2019. "Cosmopolitanism and Migrant Protests." In Routledge International Handbook of Cosmopolitanism Studies, 2nd ed., edited by G. Delanty, 419-429. Abingdon: Routledge.

Cebolla, L., and F. Ghia. 2015. "Introduction." In Cosmopolitanism: Between Ideals and Reality, edited by L. Cebolla Sanahuja and F. Ghia, 1-10. Newcastle upon Tyne, UK: Cambridge Scholars Publishing.

Delanty, G. 2006. "The Cosmopolitan Imagination: Critical Cosmopolitanism and Social Theory." The British Journal of Sociology 57 (1): 25-47.

Etinson, A. 2011. "Cosmopolitanism: Cultural, Moral, and Political." In Sovereign Justice: Global Justice in a World of Nations, edited by D. P. Aurelio, G. De Angelis, and R. Queiroz, 25-46. Berlin and New York: Walter de Gruyter. https:// doi.org/10.1515/9783110245745.1.25.

Fassin, D. 2016. "From Right to Favour: The Refugee Crisis as a Moral Question." The Nation, April 5. Available from: https://www.ias.edu/news/fassinrefugees-thenation. Accessed June 20, 2019.

Feischmidt, M., L. Pries, and C. Cantat, eds. 2019. Refugee Protection and Civil Society in Europe. Houndmills and Basingstoke: Palgrave Macmillan.

Fine, R. 2019. "The Idea of Cosmopolitan Solidarity." In Routledge International Handbook of Cosmopolitanism Studies, 2nd ed., edited by G. Delanty, 362-371. Abingdon: Routledge. 
Fleischmann, L., and E. Steinhilper. 2017. "The Myth of Apolitical Volunteering for Refugees: German Welcome Culture and a New Dispositif of Helping." Social Inclusion 5 (3): 17-27. https://doi.org/10.17645/si.v5i3.945.

Funk, N. 2016. "A Spectre in Germany: Refugees, a 'Welcome Culture' and an 'Integration Politics'." Journal of Global Ethics 12 (3): 289-299. https://doi. org/10.1080/17449626.2016.1252785.

Ghita, C. 2016. Competitive Activism. An Investigation of the Activists and Volunteers in the 2015 Refugee Crisis. MA thesis, Lund University. Available from: https://lup.lub.lu.se/student-papers/search/publication/8894736.

Glick Schiller, N. 2015. "Diasporic Cosmopolitanism: Migrants, Sociabilities and City Making." In Whose Cosmopolitanism?: Critical Perspectives, Relationalities and Discontents, edited by N. Glick Schiller and A. Irving, 103-120. New York, NY: Berghahn Books.

Glick Schiller, N. 2016. "The Question of Solidarity and Society: Comment on Will Kymlicka's Article 'Solidarity in Diverse Societies'." Comparative Migration Studies 4 (6). https://doi.org/10.1186/s40878-016-0027-x.

Glick Schiller, N., and A. Irving. 2015. "Introduction, What's in a Word? What's in a Question?" In Whose Cosmopolitanism?: Critical Perspectives, Relationalities and Discontents, edited by N. Glick Schiller and A. Irving, 1-22. New York, NY: Berghahn Books.

Hansen, C. 2019. Solidarity in Diversity: Activism as a Pathway of Migrant Emplacement in Malmö. Doctoral dissertation in International Migration and Ethnic Relations, Malmö University. Dissertation series in Migration, Urbanisation, and Societal Change, 7. Malmö: Holmbergs. http://muep.mau.se/handle/2043/ 29782.

Held, D. 2013. "Cosmopolitanism in a Multipolar World". In After Cosmopolitanism, edited by R. Braidotti, P. Hanafin, and B. B. Blaagaard, 28-39. London: Routledge.

Hansby, A., and D. J. O'Byrne. 2019. "Global Civil Society and the Cosmopolitan Ideal." In Routledge International Handbook of Cosmopolitanism Studies, 2nd ed., edited by G. Delanty, 336-350. Abingdon: Routledge.

Jäckle, S., and P. D. König. 2017. "The Dark Side of the German 'Welcome Culture': Investigating the Causes Behind Attacks on Refugees in 2015." West European Politics 40 (2), 223-251. https://doi.org/10.1080/01402382.2016. 1215614.

Karakayali, S. 2019. "The Welcomers: How Volunteers Frame Their Commitment for Refugees." In Refugee Protection and Civil Society in Europe, edited by M. Feischmidt, L. Pries, and C. Cantat, 221-241. Houndmills and Basingstoke: Palgrave Macmillan. https://doi.org/10.1007/978-3-319-92741-1_8.

Kleres, J. 2018. "Emotions in the Crisis: Mobilising for Refugees in Germany and Sweden." In Solidarity Mobilizations in the "Refugee Crisis": Contentious Moves, edited by D. della Porta, 209-241. Basingstoke: Palgrave Macmillan. 
Lewin, L. 2013. "Samling kring folkhemmet [Coming Together Around folkhem]." In Mellan folkhem och Europa [Between folkhem and Europe], edited by L. Bennich-Björkman and P. Blomqvist, 20-39. Stockholm: Liber.

Malmö stad. 2016. "Fakta och statistik [Fact and Statistics]." Available from: http://malmo.se/Kommun--politik/Fakta-och-statistik.html. Accessed January $7,2018$.

Mäkelä, F. 2016. 'Jag var tvungen att göra någonting'. Refugees Welcome to Malmö och volontärernas berättelser om flyktingkrisen hösten 2015 ['I Had to do Something'. Refugees Welcome to Malmö and the Stories of the Volunteers Regarding the Refugee Crisis During the Fall of 2015]. BA thesis, Malmö University. Available from: http://hdl.handle.net/2043/20897.

Mårs, D. 2016. Between Compassion and Privilege: Identity, Responsibility and Power Among Volunteers Engaged in Refugee Reception. MA thesis, Lund University. Available from: https://lup.lub.lu.se/student-papers/search/ publication/8887216.

Moore, H. 2013. "The Fantasies of Cosmopolitanism.” In After Cosmopolitanism, edited by R. Braidotti, P. Hanafin, and B. Blaagaard, 97-110. Abingdon: Routledge.

Nowicka, M. forthcoming. "Hospitality, Cosmopolitanism and Conviviality: On Relations with Others in Hostile Times." In On Cosmopolitanism in a Global Age, edited by V. Cicchelli and S. Mesure. Leiden: Brill.

Pendenza, M. 2017. "Societal Cosmopolitanism: The Drift from Universalism Towards Particularism." Distinktion: Journal of Social Theory 18 (1): 3-17. https://doi.org/10.1080/1600910x.2017.1290668.

Povrzanović Frykman, M. 2016. “Cosmopolitanism in Situ: Conjoining Local and Universal Concerns in a Malmö Neighbourhood." Identities: Global Studies in Culture and Power 23 (1): 35-50 (special issue "Seeing Place and Power", edited by N. Glick Schiller and G. Schmidt). https://doi.org/10.1080/1070289x. 2015.1016525.

Povrzanović Frykman, M., and F. Mäkelä. 2019. “'Only Volunteers’? Personal Motivations and Political Ambiguities within Refugees Welcome to Malmö civil Initiative." In Refugee Protection and Civil Society in Europe, edited by M. Feischmidt, L. Pries, and C. Cantat, 291-318. Houndmills and Basingstoke: Palgrave Macmillan. https://doi.org/10.1007/978-3-319-92741-1_11.

Pries, L. 2019. "Introduction: Civil Society and Volunteering in the So-Called Refugee Crisis of 2015-Ambiguities and Structural Tensions." In Refugee Protection and Civil Society in Europe, edited by M. Feischmidt, L. Pries, and C. Cantat, 1-23. Houndmills and Basingstoke: Palgrave Macmillan. https://doi. org/10.1007/978-3-319-92741-1_1.

Rancière, J. 1999. Disagreement: Politics and Philosophy. Minneapolis: University of Minnesota Press. 
Rancière, J. 2010. Dissensus: On Politics and Aesthetics. London: Continuum Publishing Group.

Rescala, I. 2016. Why Do Volunteers Help: A Qualitative Study of Volunteer's Reasons to Help in the Reception of Refugees in Malmö 2015. MA thesis, Master of Applied Cultural Analysis (MACA), Lund University. Available from: https://lup.lub.lu.se/student-papers/search/publication/8906097.

Siapera, E. 2019. "Refugee Solidarity in Europe: Shifting the Discourse." European Journal of Cultural Studies. Online first. https://doi.org/10.1177/ 1367549418823068.

Skrbiš, Z., and I. Woodward, eds. 2013. Cosmopolitanism: Uses of the Idea. Los Angeles, London, and New Delhi: Sage.

Spurk, C. 2010. 'Understanding Civil Society'. In Civil Society \& Peacebuilding: A Critical Assessment, edited by T. Paffenholz, 3-27. Boulder and New York: Lynne Rienner.

Svedberg, L., and L. Trägårdh, eds. 2006. Det civila sambället som forskningsfält. Nya avhandlingar $i$ ett nytt sekel [Civil Society as a Research Field. New Dissertations in a New Century]. Stockholm: Riksbankens jubileumsfond \& Gidlunds förlag.

Tanner, A. 2016. “Overwhelmed by Refugee Flows, Scandinavia Tempers Its Warm Welcome." Migration Information Source, February 10. Available from: https://www.migrationpolicy.org/article/overwhelmed-refugeeflowsscandinavia-tempers-its-warm-welcome. Accessed June 11, 2019.

Trujillo, I. 2015. "Cosmopolitanism and Human Rights." In Cosmopolitanism: Between Ideals and Reality, edited by L. Cebolla Sanahuja and F. Ghia, 10-34. Newcastle upon Tyne: Cambridge Scholars Publishing.

Turinsky, T., and M. Nowicka. 2019. "Volunteer, Citizen, Human: Volunteer Work Between Cosmopolitan Ideal and Institutional Routine." In Refugee Protection and Civil Society in Europe, edited by M. Feischmidt, L. Pries, and C. Cantat, 243-268. Houndmills and Basingstoke: Palgrave Macmillan. https://doi.org/ 10.1007/978-3-319-92741-1_9.

Vandevoordt, R., and G. Verschraegen. 2019. "Subversive Humanitarianism and Its Challenges: Notes on the Political Ambiguities of Civil Refugee Support." Refugee Protection and Civil Society in Europe, edited by M. Feischmidt, L. Pries, and C. Cantat, 101-128. Houndmills and Basingstoke: Palgrave Macmillan. https://doi.org/10.1007/978-3-319-92741-1_4.

Wilkinson, I. 2019. "Humanitarianism and Cosmopolitanism." In Routledge International Handbook of Cosmopolitanism Studies, 2nd ed., edited by G. Delanty, 372-382. Abingdon: Routledge. 
Open Access This chapter is licensed under the terms of the Creative Commons Attribution 4.0 International License (http://creativecommons.org/licenses/by/ $4.0 /$ ), which permits use, sharing, adaptation, distribution and reproduction in any medium or format, as long as you give appropriate credit to the original author(s) and the source, provide a link to the Creative Commons license and indicate if changes were made.

The images or other third party material in this chapter are included in the chapter's Creative Commons license, unless indicated otherwise in a credit line to the material. If material is not included in the chapter's Creative Commons license and your intended use is not permitted by statutory regulation or exceeds the permitted use, you will need to obtain permission directly from the copyright holder.

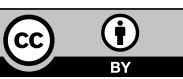

